\title{
セメントの水和と内部水の粘性からみた
}

\author{
コンクリートのクリープ特性
}

\section{CREEP OF CONCRETE IN THE LIGHT OF HYDRATION OF CEMENT AND VISCOSITY OF INTERNAL WATER}

\author{
河 角 誠* - 関 慎 吾** 一笠 原 清*** ・ 栗 山武雄**** \\ By Makoto KAWASUMI, Shingo SEKI, Kiyoshi KASAHARA \\ and Takeo KURIYAMA
}

\section{1. まえがき}

コンクリート大ダムや原子炉用 PC 容器および PC 橋 梁のような重要な構造物の解析・設計と安全性の評価の ためには，コンクリートのクリープを定量的に把握し， 一般的な表示を行っておかなければならない.

そのためには, 地道な実験結果の蓄積に加え, クリー プの微視的機構に注目する必要がある.この観点に立 ち, さきに, 高温クリープの実験に関連し, 水の粘性と セメントの水和を考虑に入れたクリープ・モデルを提出 した ${ }^{1), 2)}$.

今回，密封セメント・ペーストの水和測定を行い，ク リープ・データをこのモデルによって, 具体的に解析で きるよらになったので，その結果を報告する.

本来ならここで，コンクリートのクリープ研究の展望 を述べるべきであるが，それは Neville の大著(6)譲り， ただ，筆者らは T.C. Powersによる硬化したセメント. ペーストの内部構造の描写から大きな影響を受けたこ と，また以下に述べる観点に立った研究は，ほとんどみ られないことを申し添えておく.

\section{2. セメントの水和}

水中養生セメント・ペースト（中庸熱ボルトランド・ セメント）の結合水量の測定結果から，常温でのセメン トの水和進行を次式で表わせることをすでに示した ${ }^{1), 2) . ~}$

$$
\frac{d C_{H}(t)}{d t}=k_{0}(1-n) t^{-n}\left(W-r C_{H}(t)\right)\left(C-C_{H}(t)\right)
$$

* 正会員 (財) 電力中央研究所土木技術研究所 (現工博)

** 正会員 工博 日本大学教授理工学部次長 理工学研究所長 *** 正会員 (財) 電力中央研究所土木技術研究所

**** (財) 電力中央研究所土木技術研究所
ただし， $C_{H}(0)=0,0<n<1$. ここに, $t:$ セメント・ペーストの材令 (日), $C:$ セメ ント・ペースト $1 \mathrm{~m}^{3}$ 中のセメント量 $\left(\mathrm{kg} / \mathrm{m}^{3}\right), W:$ ペ 一ス卜 $1 \mathrm{~m}^{3}$ 中の水量 $\left(\mathrm{kg} / \mathrm{m}^{3}\right), C_{\boldsymbol{H}}(t)$ : ペースト $1 \mathrm{~m}^{3}$ 中の材令 $t$ 日までに水和したセメント量 $\left(\mathrm{kg} / \mathrm{m}^{3}\right), k_{0}$, $n:$ 水和を表わすパラメーター, $r:$ 完全結合水量 $(1 \mathrm{~g}$ のセメントを完全に水和させるのに必要な水量) $(\mathrm{g} / \mathrm{g})$.

式 (1) の解は,

$$
\begin{aligned}
\frac{C_{H}(t)}{C} & =R_{H}(t) \\
& = \begin{cases}\frac{1-\exp \left\{(r C-W) k_{0} t^{1-n}\right\}}{1-\frac{C}{W} \exp \left\{(r C-W) k_{0} t^{1-n}\right\}} \cdots \cdots(2) \\
\frac{r k_{0} t^{1-n}}{\frac{1}{C}^{2}+r k_{0} t^{1-n}} & (W / C \neq r)\end{cases}
\end{aligned}
$$

ここに, $R_{H}(t)$ はセメントの水和進行率である.

今回, 試験管密封養生した普通および中庸熱ポルトラ ンド・セメント・ペーストの結合水量を $20 \sim 80^{\circ} \mathrm{C}$ の範 囲で, 表一1 に示す条件によって，重量法で測定した （測定法は文献 3）参照. なお，その概略を述べれば, 密 封養生したセメント・ペーストを所定の材令で粉砕し，

\begin{tabular}{|c|c|c|}
\hline セメントの種類 & $\begin{array}{l}\text { 普通ポルトラント・ } \\
\text { セメン }\end{array}$ & $\begin{array}{l}\text { 中唐熱ポルトランド } \\
\text { セメント }\end{array}$ \\
\hline 製 造工場 & 日本セメント埼玉工場 & 小野田セメント藤原工場 \\
\hline 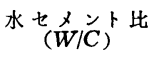 & \multicolumn{2}{|c|}{$40 \%$} \\
\hline 食 生 方 法 & \multicolumn{2}{|c|}{ 試戨管密封飬生 } \\
\hline 瀁生温度 $\left({ }^{\circ} \mathrm{C}\right)$ & \multicolumn{2}{|c|}{$20,30,40,50,60,70,80$} \\
\hline $\begin{array}{c}\text { 標準測定材令 } \\
(\text { 日)* }\end{array}$ & \multicolumn{2}{|c|}{$3,5,7,14,28,56,91,98,182,365,546,553,735$} \\
\hline
\end{tabular}
ふるい分け，デシケータで真空乾燥し，電気炉で強熱

\section{表一1 セメントの結合水是の測定条件}

*ただし後期材令で，高温のものほど化合物の膨張作用によって，試験 管が破翌するものが出るので測定から除外した。 
し，この間消失した水分を結合水量としたものである). 式（2)，(3) でのあてはめの際，完全結合水量は，前回 は水中養生の場合として $r=0.37(37 \%)$ を採用し，そ の根拠を詳述した ${ }^{3)}$. 今回の密封養生の場合は $r=0.37$ と 0.25 で解析を行った（前回 $r=0.37$ としたのは, 水 中養生についてのセメントの専門家の意見に従ったから であり, 今回 $r=0.25$ を加えたのは, ここで示す密封 養生の場合, これが測定された結合水量の上限值であっ たからである. そして両者を，一応完全結合水量の上下

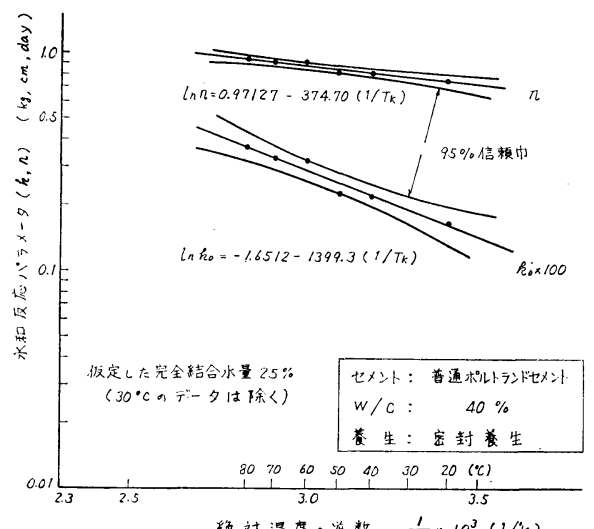

図一1 セメントの水和パラメーターの温度依存性

（普通ポルトランド・セメント）

表一2 セメントの水和パラメーター*

[cm, kg, day]

\begin{tabular}{|c|c|c|c|c|c|}
\hline & & \multicolumn{2}{|c|}{ 普通ポルトランド・セメント } & \multicolumn{2}{|c|}{ 中庸熱ポルトランド・セメント } \\
\hline \multicolumn{2}{|c|}{ 完全結合水量 (\%) } & 25 & 37 & 25 & 37 \\
\hline$k_{0}$ & $\begin{array}{c}\text { (CONSTK) } \\
\text { COFFK } \\
\text { CLINK }\end{array}$ & $\begin{array}{r}(-1.6512) \\
0.19182 \\
-1399.3\end{array}$ & $\begin{array}{r}(-3.5284) \\
0.02935 \\
-978.97\end{array}$ & $\begin{array}{l}(0.070604) \\
1.0732 \\
-1985.0\end{array}$ & $\begin{array}{r}(-2.1608) \\
0.11523 \\
-1450.5\end{array}$ \\
\hline$n$ & $\begin{array}{c}\text { (CONSTN) } \\
\text { COFFN } \\
\text { CLINN }\end{array}$ & $\begin{array}{c}(0.97127) \\
2.6413 \\
-374.70\end{array}$ & $\begin{array}{c}(0.61146) \\
1.8431 \\
-234.24\end{array}$ & $\begin{array}{r}(1.4727) \\
4.36099 \\
-537.53\end{array}$ & $\begin{array}{l}(0.97453) \\
2.6499 \\
-354.27\end{array}$ \\
\hline
\end{tabular}

* $\mathrm{CONSTK}=\ln (\mathrm{COFFK}), \mathrm{CONSTN}=\ln (\mathrm{COFFN})$

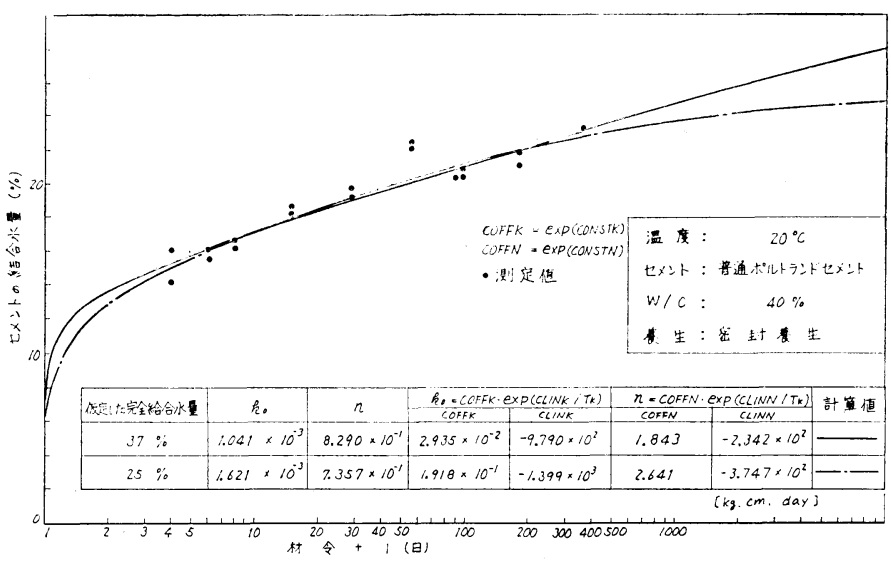

図一2 $20^{\circ} \mathrm{C}$ におけるセメントの水和（実測と計算）
の限界と考えたわけである)。

その結果式 (1) 中の $k_{0}$ と $n$ は次のような温度依存 性を示した。

$$
\begin{aligned}
k_{0} & =\mathrm{COFFK} \exp \left(\mathrm{CLINK} / T_{K}\right) \\
n & =\mathrm{COFFN} \exp \left(\mathrm{CLINN} / T_{K}\right)
\end{aligned}
$$

ここに, $\operatorname{COFFK}(>0), \operatorname{CLINK}(<0), \operatorname{COFFN}(>0)$, CLINN $(<0)$ は定数で, $T_{K}$ は絶対温度 $\left({ }^{\circ} \mathrm{K}\right)($ 図一1, 表一2 参照). 恒温槽には冷凍装置が付属しておらず， $30^{\circ} \mathrm{C}$ の槽は夏期にはこの温度を超えることがあったの で，解析からは除外した。 図一2 には， $20^{\circ} \mathrm{C}$ でのあて はめの例を，図一3〜4 にはすべての測定温度での計算 值をまとめて示す．高温養生の効果は初期には著しい が，やがて低温養生のものに追い越されていく．普通セ メントの方が中庸熱セメントよりも水和が速いことも示 されている.

ここで, 標準温度 $T_{1}^{\circ}$ (たとえば $20^{\circ} \mathrm{C}$ ) のもとで $t_{1}$ 日 間養生したのと同じ水和度に $T_{2}{ }^{\circ}$ では何日で到達できる かを等価水和材令 $\left(t_{e q}\right)$ と名づけることにすれば,

$$
t_{e q}=\left(\frac{k_{1}}{k_{2}}\right)^{\frac{1}{1-n_{2}}} t_{1}^{\frac{1-n_{1}}{1-n_{2}}}
$$

となる.ただし $k_{1}$ と $n_{1}, k_{2}$ と $n_{2}$ はとれぞれ $T_{1}^{\circ}$ と $T_{2}^{\circ}$ における水和パラメーターである.この関係を図一 5 に示す.

温度変化のある場合，式（1）で $t$ を陽に含んだまま 温度条件を入れて積分し，階段状温度上 昇下の水和の解と実験值とを比較したと ころ, 計算值は実験值に十分には追従で きなかった.そこで（2)，(3) 両式の解 を用い，式 (1) の右辺から $t$ を消去し て, 温度変化のある場合も扱える水和進 行式 (7)，(8) を得た.

$\frac{d C_{H}(t)}{d t}$

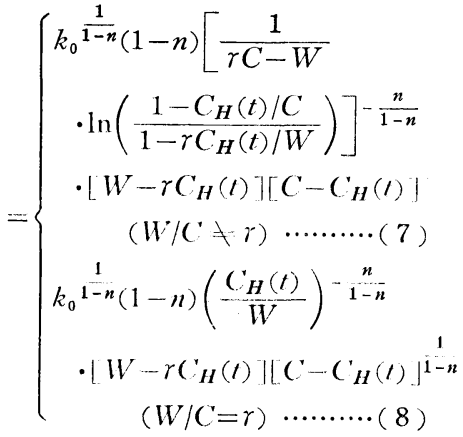

この)式を， $\left.0 \leqq t<t_{1} \sigma\right)$ とき $T=T_{1}{ }^{\circ}\left(k_{0}\right.$ $\left.=k_{1}, n=n_{1}\right), t \geqq t_{1}$ のとき $T=T_{2}^{\circ}\left(k_{0}\right.$ $\left.=k_{2}, n=n_{2}\right)$ の条件で解けば， $t \geqq t_{1}$ の 解は, 


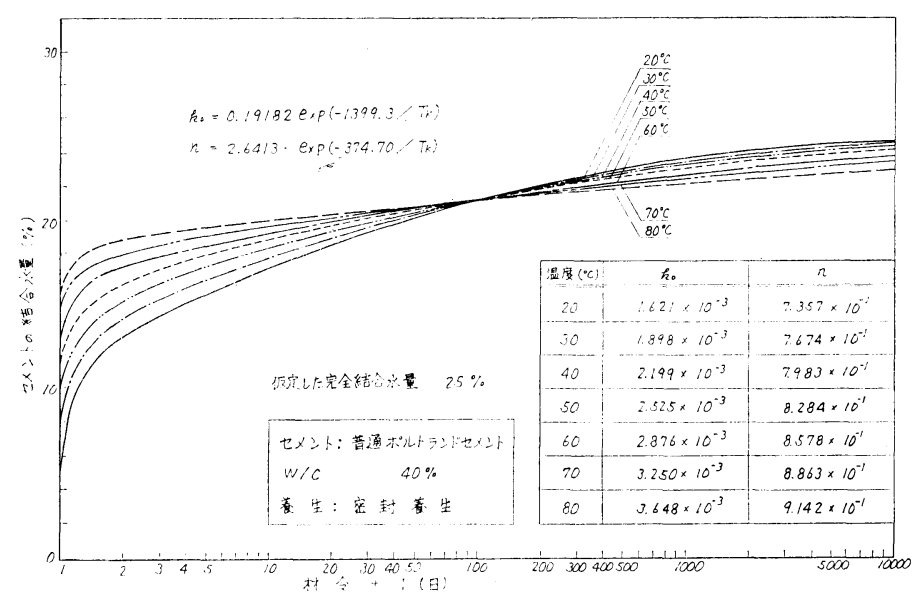

图３各温度におけるセメントの水和（a）（滔通ポルトランド・セメント）

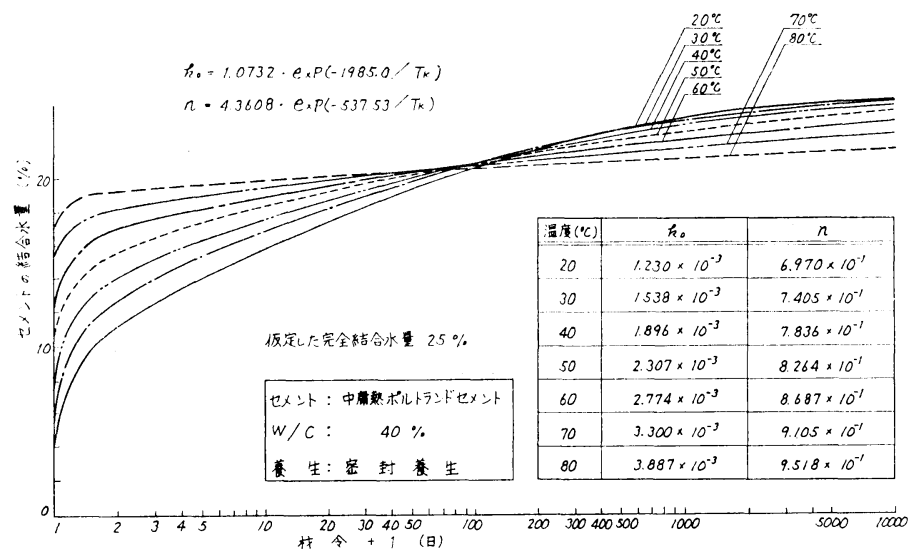

図-4 各温度におけるセメントの水和（b)（中庸熱ポルトランド・セメント）

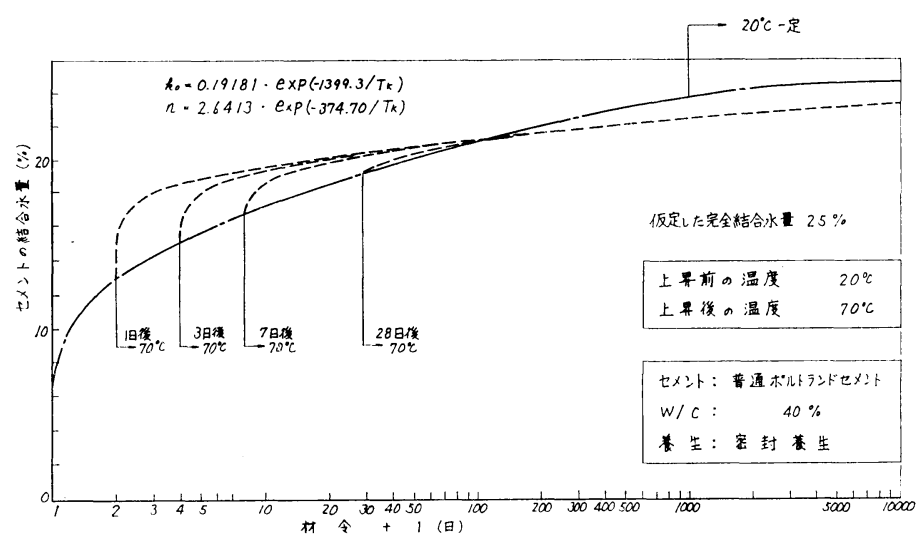

図一6 階段状温度変化のもとでのセメントの水和

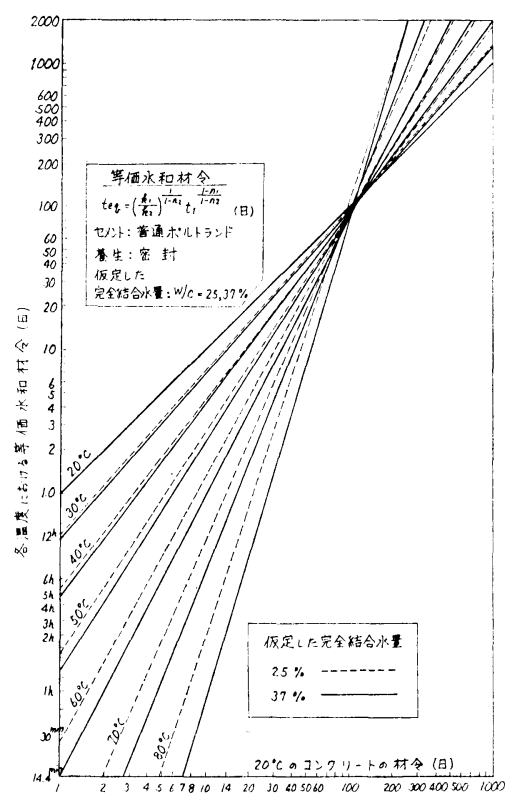

図 5 標準瀁生に対する各温度での 等価水和材令

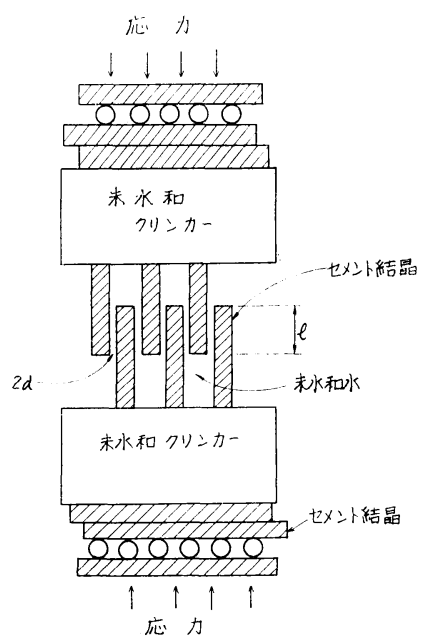

図一7水の粘性とセメントの水和を考慮 したセメント・ペーストの一次元 レオロジー・モデル

ある.図一6には種々の材令で温度を階 段状に上昇させた場合の計算例を示す. 今後, 精密な測定方法を用いてこの方程 式の適合性を確かめる必要がある.

\section{3. セメントの水和と内部水の粘性を考慮した コンクリートのレオロジー・モデル}

密封したコンクリートを対象として，図一7 に示すモ デルを考え，下記の仮定に基づきレオロジー方程式を求

となる.ただし $t_{e q}$ は式 (6) で定義した等価水和材令で 
めた'1),2).

（1）水和の進行に伴い結晶の数は増加するが, 大き さは不変であることを示した Powers \& Brownyard の 実験結果 ${ }^{4)}$ を採用し，カルシウム・ハイドロシリケート の針状結晶を円柱で近似する.

(2) 微小時間 $d t$ 後のクリープひずみの増分 $\left(d \varepsilon_{c}\right)$ は応力が大きいほど, 結晶間の水の層の厚さ $(2 d)$ が増 加するほど大きくなる. 他方, この増分は隣接する結晶 の接触長さ $(l)$, 水の粘性 $(\eta)$ と結晶の数 $(m)$ が増加 するほど小さくなる.

（3）コンクリートのクリープは，コンクリート中の ペースト量に近似的に比例する.

クリープ回復は無視したが，それは解析し得るデータ が少なく, またこの成分は君島・北原 ${ }^{5)}$ の実験結果など から比較的小さいと思われ，さらにWittmann ${ }^{6)}$ のよう な生粋の物理学者や Parrot $^{7)}$ のようなセメント化学に造 詣の深い人々がコンクリートのクリープの主体は非回復 性であるとしているからである. クリープ回復のデータ が整った暁には, T.C. Powers ${ }^{10)}$ と Bažant ${ }^{11)}$ の熱力学 的理論による回復成分を用いて，下記のモデルを改良で きるであろら・

上記の仮定のもとで, $d \varepsilon_{c} \propto d^{p} \sigma^{q} d t / \eta^{s} l^{a}$

となる (既報1),2) では $q=2$ の場合のみを考えた). 他 方, 結晶の長さを $h$, 半径を $r$ として, 荒い近似で, $d \propto V_{U W} / 2 \pi r h m$

また $, m \propto V_{H C}+V_{H W} \propto V_{H C}, l \propto \varepsilon_{c}$,

ここに, $V_{U W}$ : 未水和水の体積, $V_{H C}$ : 水和したセメ ントの体積, $V_{H W}$ : セメントと化合した水の体積.

応力変化のない場合にはクリープひずみは応力に比例 するとして（これは応力が過大でないときに実験的に認 められている), $a+1=q$, さらに $q=1$ のとき, このモ デルが Maxwell モデルに一致するように, $q=s$ とす る.

ここで,

$$
\eta_{*}(t) \equiv \eta\left[V_{H C} / V_{U W}\right]^{p / q} /\left(q A_{1}\right)^{1 / q}
$$

ここに $A_{1}$ はペースト量と骨材の種類によって定まる定 数.

とおけば,この $\eta_{*}(t)$ は $q=1$ のとき粘性係数と一致す るので,これを $q \neq 1$ のとき, 擬似粘性係数とよぶこと にする. 密封コンクリートの弾性係数が材令とともに変 化するときには, 階段状の応力変化を加えた場合, “弾 性”ひずみ成分も階段状に変化し, 弾性係数が材令につ れて増加しても, 荷重を押し返すことはないので, 瞬間 変形部分は亜弾性的であると考えるべきであるから，圧 縮応力と圧縮ひずみを正とすると, 任意の圧縮応力状態 のもとでのひずみを表わす次式を得る.

$$
\begin{aligned}
\varepsilon\left(t-t_{1}\right)= & \int_{t_{1}}^{t} \frac{1}{E_{i}(s)} \frac{d \sigma(s)}{d s} d s \\
& +\left[\int_{t_{1}}^{t}\left(\frac{\sigma(s)}{\eta_{*}(s)}\right)^{q} d s\right]^{1 / q}
\end{aligned}
$$

ここに, $t:$ コンクリートの材令 (日), $t_{1}$ : 載荷時の材 令 (日), $\varepsilon\left(t-t_{1}\right):$ 載荷後 $\left(t-t_{1}\right)$ 日における弾性ひず みとクリープひずみの和, $\sigma(s)$ : 材令 $s$ 日における応 力 $\left(\mathrm{kgf} / \mathrm{cm}^{2}\right), E_{i}(s)$ : 材令 $s$ 日における瞬間弾性係数 $\left(\mathrm{kgf} / \mathrm{cm}^{2}\right)$ (この係数は, 載荷直後の瞬間ひずみと, 載 徛応力から求めた弾性係数である).

一定温度のもとでの $\eta_{*}(t)$ を具体的に表わせば, $\eta_{*}(t)$

$$
=\left\{\begin{array}{c}
\frac{\eta}{\left(q A_{1}\right)^{1 / q}}\left(\frac{\rho_{W}}{\rho_{C}}\right)^{p / q}\left[\frac{1-\exp \left\{(r C-W) k_{0} t^{1-n}\right\}}{W / C-r}\right]^{p / q} \\
(W / C \neq r) \cdots \cdots \cdots \cdots \cdots(12) \\
\frac{\eta}{\left(q A_{1}\right)^{1 / q}}\left(\frac{\rho_{W}}{\rho_{C}}\right)^{p / q}\left(k_{0} C\right)^{p / q} t^{(1-n) p / q} \\
(W / C=r) \cdots \cdots \cdots \cdots \cdots(13)
\end{array}\right.
$$

ここに, $\rho_{W}$ と $\rho_{C}$ はそれぞれ水とセメントの密度であ る.上記の式において, 温度による水の粘性の変化は,

$$
\eta=A_{v} \exp (E / R T)
$$

によって表わされる.ここに，T: 絶対温度 $\left({ }^{\circ} \mathrm{K}\right), E$ : 内部水の活性化エネルギー, $R$ : 気体定数, $A_{v}$ : 定数.

このモデルの検討から, 重ね合わせ法がクリープ回復 を過大評価する原因は, Boltzmann の重盢積分の中に応 力非線形粘性成分を含ませるため, 本来非回復の成分を 回復成分とみなすことになるからであると考えられた.

\section{4. モデルから得られるクリープ曲線式}

式 (11) で $\sigma=1\left(t \geqq t_{1}\right)$ とおいて, 載荷後 $\left(t-t_{1}\right)$ 日 における単位応力当たりのクリープひずみ $\varepsilon_{c}\left(t-t_{1}\right)$ と して次の式 $(15) \sim(17)$ を得る.

$\varepsilon_{c}\left(t-t_{1}\right)=$

$$
\left\{\begin{array}{c}
A_{4} \exp \left(-\frac{E}{R T}\right)\left\{\int _ { t _ { 1 } } ^ { t } \left[\frac{W / C-r}{(W / C \neq r) \cdots \ldots \ldots \ldots \cdots(15)}\right.\right. \\
A_{4} \exp \left(-\frac{E}{R T}\right)\left[\left(\frac{1}{k_{0} C}\right)^{p} \frac{1}{(1-n) p-1}\right. \\
\left.\cdot\left\{t_{1}^{1-(1-n) p}-t^{1-(1-n) p}\right\}\right]^{1 / q} \\
(W / C=r, \text { かつ }(1-n) p-1 \neq 0) \cdots \cdots(16) \\
A_{4} \exp \left(-\frac{E}{R T}\right)\left[\left(\frac{1}{k_{0} C}\right)^{p} \ln \left(1+\frac{t-t_{1}}{t_{1}}\right)\right]^{1 / q} \\
(W / C=r, \text { かつ }(1-n) p-1=0) \cdots \cdots \cdots(17)
\end{array}\right.
$$

ここに, $t$ : コンクリートの材令 (日), $T$ : コンクリー 卜の絶対温度 $\left({ }^{\circ} \mathrm{K}\right), C$ : セメント・ペースト $1 \mathrm{~m}^{3}$ 中の セメント量 $\left(\mathrm{kg} / \mathrm{m}^{3}\right), W$ : セメント・ペースト $1 \mathrm{~m}^{3}$ 中 の水量 $\left(\mathrm{kg} / \mathrm{m}^{3}\right) . A_{4}, p, q$ : クリープ定数. ただし, $A_{4}$ 
は骨材の種類やペースト量によって決まり，温度にはあ まり影響されないものと考えられる。

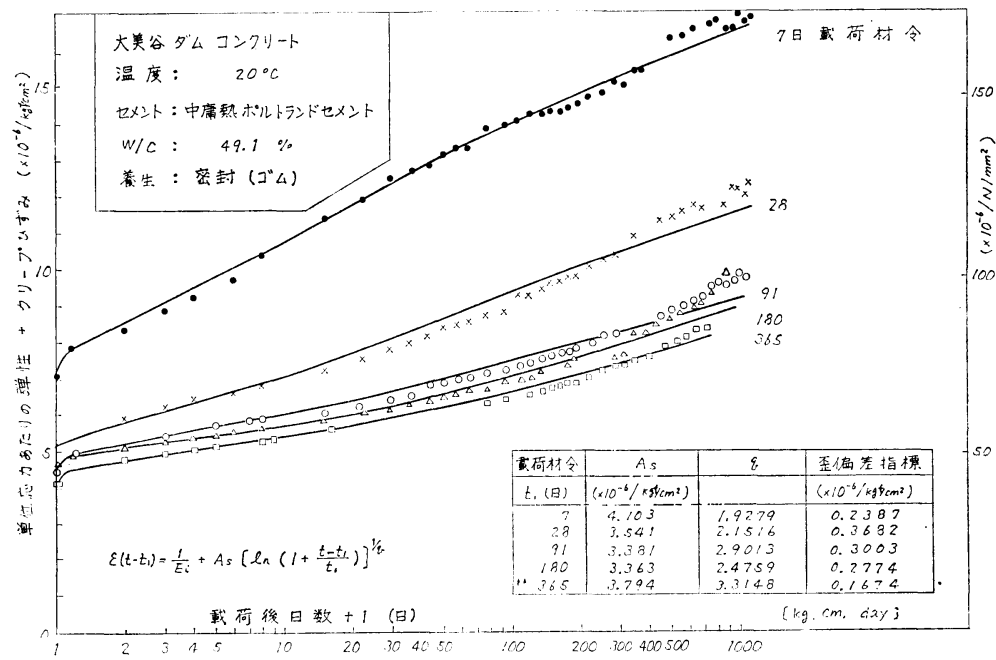

図一8 最簡単近似式によるクリープ曲線のあてはめ

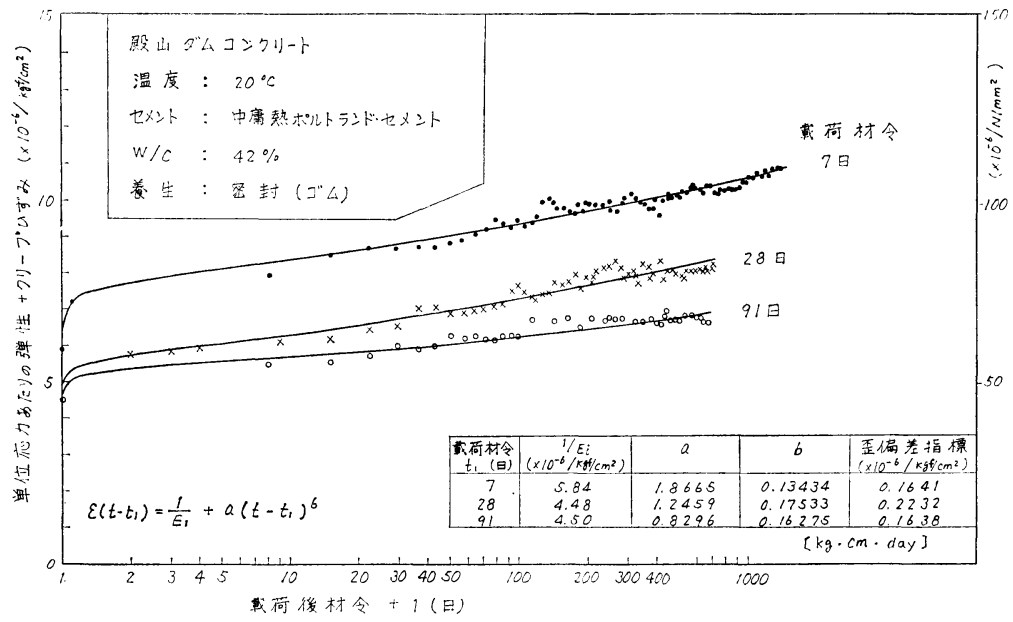

図一9 ベき関数式によるクリープ曲線のあてはめ

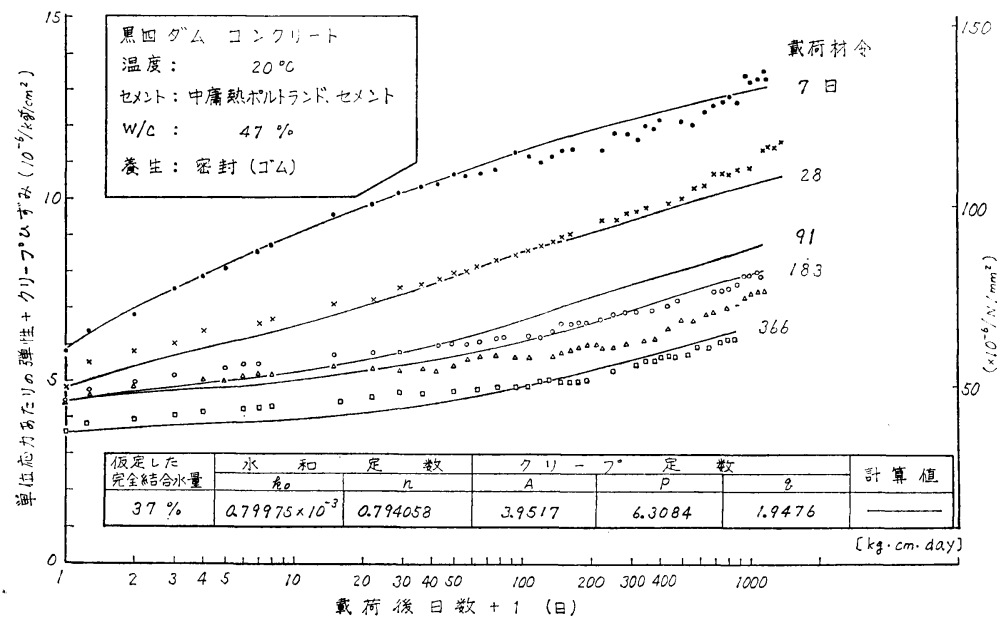

図一10 積分型クリープ曲線のあてはめ
ここで式 (17) を $W / C \neq r$ のときも近似式として使

うことを考え，このときこれを“最簡単近似式”，また 最も一般的な式 (15) を“積分 型”とよぶ. 図一8には最簡単 近似式をあてはめた結果を示 す.なお図中の $A_{s}$ は,

$$
\begin{aligned}
A_{s}= & A_{4} \exp (-E / R T) \\
& \cdot\left(1 / k_{0} C\right)^{p / q} \ldots \ldots
\end{aligned}
$$

である.また式（15)〜 (17) は 後述のようにべき関数式に密接 に関係があるので, 次の式 (19) をあてはめた結果を図一9に示 于.

$$
\varepsilon\left(t-t_{1}\right)=1 / E_{i}+a\left(t-t_{1}\right)^{b}
$$

ここに， $a$ : 載荷材令によって 決まるパラメーター, $b$ : 定数. これらの式は個々の曲線の近似 としてはきわめてよくあてはま っているので, 積分型曲線を求 める過程で必要になるクリープ 曲線の微分值の計算に利用し た.

図-10 には黒部第 4 ダム・ コンクリートに積分型クリープ 曲線をあてはめた結果を示す. これを求める際に, $k_{0}$ と $n$ は 水和実験から， $q$ の初期值とし ては最簡単近似式の $q$ を, 実験 曲線の微分值はべき関数式と最 簡単近似式のうちあてはまりの よい方から求め, 残りの定数 $A$ と $p\left(A=A_{4} \exp (-E / R T)\right)$ を 最小自乗法で求め, これより Gauss の積分法を用いて，クリ ープひずみを計算し，ひずみ偏 差の自乗和を最小にする $A, p$, $q$ を $q$ の逐次微小変化によって 求めた. 倍精度計算によれば, $q$ を有効数字 6 桁まで決定でき た.なお，あてはまりの程度を 示すため次式から求まる $d_{\mathrm{crp}}$ をひずみ偏差指標と名づけた.

$$
\begin{aligned}
d_{\mathrm{crp}}= & \sqrt{\sum_{i=2}^{N}\left[C_{i}\left(t_{i}\right)\right.} * \\
& * \frac{\left.C_{\mathrm{cal} i}\left(t_{i}\right)\right]^{2} /(N-1)}{}
\end{aligned}
$$


ここに, $C_{i}\left(t_{i}\right):$ 材令 $t_{i}$ 日におけるクリープひずみの 測定值, $C_{\mathrm{cal} i}\left(t_{i}\right)$ : 同計算值, $N$ : デー夕数. ただし載 荷直後のひずみには誤差がないとして，測定したひずみ から載荷直後のひずみを差し引いて，クリープひずみの 測定值とした.

な抢供試体は直径 $15 \mathrm{~cm}$, 高さ $60 \mathrm{~cm}$ の円柱形で, 中 心にゲージ長 $25 \mathrm{~cm}$ のカールソン型ひずみ計を埋め込 み, ゴムシールし, 油圧装置で載荷した。温度は $20^{\circ} \mathrm{C}$ 一定で供試体 2 本のひずみの平均值を, 無載荷供試体 2 本のひずみで補正し，力学的ひずみを求めた.

式（15） は水セメント比の影響も表わしているので, ペースト量を一定とし, 水セメント比を変化させた実験 を行い, $W / C=40 \%$ の実験から求めたクリープ・パラ メーター $A, p, q$ にって $, W / C=35,50 \%$ のクリー プ曲線を計算し, 実験值とともに 図一11に示した. こ の場合, 供試体は $0.2 \mathrm{~mm}$ の銅板でシールしたものであ る.

な抒式 (17) は $q=1$ のとき, 米国開拓局の対数式 ${ }^{8)}$ に類似したものとなる。ただし実際には $q$ はすでにみた ように 2 3 程度である.

特殊な場合のクリープ曲線は，

（1）載荷直後—いずれの場合もクリープひずみは $\left(t-t_{1}\right)^{1 / q}$ に比例する.

（2）載荷後長期間経過したとき

(a) セメントが過剩 $(r C-W>0)$ の場合はクリ ープは停止する.

（b）水分が過剩 $(r C-W<0)$ の場合は $\varepsilon_{c}\left(t-t_{1}\right) \longrightarrow\left(t-t_{1}\right)^{1 / q} / \eta_{*}(\infty)$

(c) $r C-W=0$ のとき—クリープひずみは一 定值に近づくか (式 (16)), クリープ速度が零に 近づく（式 (17). 実験的に $(1-n) p-1>0$ が 一般的である).

このモデルによれば, クリープの最終的な挙動はコン
クリート中に水分が残っているか否か $(W / C)$ にって 決まる．これは完全に乾燥したコンクリートではほとん どクリープが生じないという Hannant の結果 ${ }^{6)}$ に対応 する.

以上の吟味から，このモデルのクリープ式はべき関数 にきわめて関係が深いことがわかる、事実べき関数式

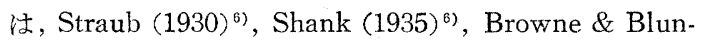
dell $\left.(1969)^{6}\right)$ らによって用いられ, 最近 Bažant ${ }^{9}$ は は次 のべき関数式を提案し, 精力的にあてはめを行ってい る.

$$
\varepsilon\left(t-t_{1}\right)=\frac{1}{E_{0}}+\frac{\phi_{1}}{E_{0}} t_{1}-m_{B}\left(t-t_{1}\right)^{n_{B}}
$$

ここに, $\phi_{1}, m_{B}, n_{B}$ は定数. この式はモデルから特殊 な場合として得られ, この式の成立範囲も, $n_{B}$ と $m_{B}$ の具体的な值も明らかとなる(すなわち $n_{B}=1 / q, m_{B}=$ $(1-n) p(q) \cdot m_{B}$ 注載荷時の材令へのクリープの依存性 学表わす。

\section{5. 他のクリープ計算法との関係}

上記のモデルによる計算法はその特別な場合として, 時間硬化法 ${ }^{12)}$ とひずみ硬化法 ${ }^{12)}$ を含んでいる. 時間硬化 法では時間の経過が硬化の原因となると考えている.こ れは水和の進行によってコンクリートが硬化することに 関連づけられる。一方ひずみ硬化法では，ひずみによっ て材料が硬化して，それ以後のひずみの進行を妨げると 考えており，硬化したセメント・ペーストに圧縮力が加 えられることにより，セメントの水和による微小な針状 結晶のからみ合いが増加して, クリープの進行が妨げら れることを表わしていると解勫される.したがってコン クリートのクリープではこれら 2 つの現象が同時に起こ っているとみるのが妥当であるら，以下モデルとの関連 を調べる.

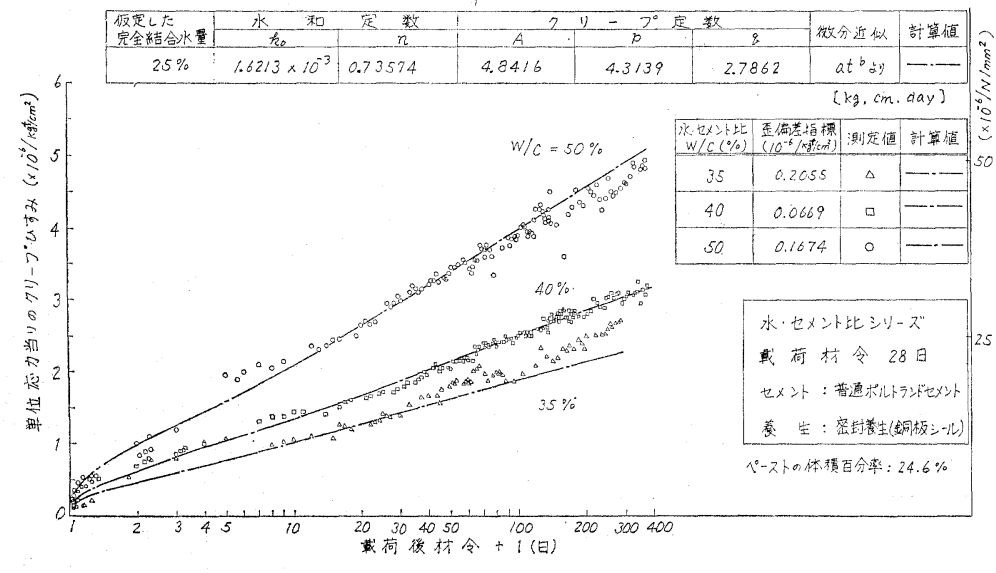

図一11 $W / C=40 \%$ のクリープ実験から求めたクリープ定数 による $W / C=35,50 \%$ のクリープひずみと実測値

\section{（1）時間硬化法・クリープ 速度法との関連性}

Odqvist と Hult ${ }^{12)}$ とよれば， 時間硬化法注

$$
d \varepsilon_{c} / d t=A_{H} \sigma^{l_{H}} t^{-\lambda} \ldots
$$

によって表わされる.ここに $A_{H}, l_{H}, \lambda$ は定数. 金属クリー プでは $\lambda<1$ とされており，こ れは式 (23) の積分のために必 要である.コンクリートの場合 は式 (13) で $q=1$ としたとき に $\lambda=(1-n) p \geqq 1$ の場合が現 われる.この場合もコンクリー 
トでは積分の下限 $t_{1}$ は零になれないので（コンクリー 卜は硬化していない), 式 (23) は積分可能となる.

式 (11) 中のクリープ成分で $q=1$, かつ $\eta_{*}(t)=t^{2} / A_{H}$ とすれば,ここで示したモデルは時間硬化モデルで $l_{H}$ $=1$ とした場合と一致する.このとき応力を一定にした 場合のクリープひずみは応力に比例する.これは $W / C$ $=r$ で, $\eta_{*}(t)$ が式 (13) で表わせる場合である. 時間 硬化の定義を抁張して, $d \varepsilon_{c} / d t=g(\sigma, t)$ とすれば, $W / C$ $\neq r$ のときも $q=1$ である限りモデルは時間硬化モデル に一致する.

Nevilleの表現 ${ }^{6}$ に従い，さらに瞬間変形部分を亜弾性 的だとすれば, クリープ速度法は次式で表わされる.

$$
\begin{aligned}
\varepsilon\left(t-t_{1}\right)= & \int_{t_{1}}^{t} \frac{1}{E_{i}(s)} \frac{d \sigma}{d s} d s \\
& +\int_{t_{1}}^{\sigma} \sigma \frac{d C_{s p}}{d t} d s \cdots
\end{aligned}
$$

ここに, $C_{s p}$ は単位応力当たりのクリ ープである. 上式を微分して $d C_{s p} / d^{t}$ $=1 / \eta(t)$ とおくことにより, 式 (24) は時変数レオロジー・パラメーターを 有する Maxwell モデルの式であるこ とがわかる. そしてこれは式 (11) で $q=1$ とした場合そのものである.こ れは Dischinger 法でもある。

\section{（2）ひずみ硬化法との関連性}

ひずみ硬化法は次式で表わされる。

$$
d \varepsilon_{c} / d t=B_{H} \sigma^{m_{H}} \varepsilon^{-\mu}
$$

ここに, $B_{H}, m_{H}, \mu$ は定数. クリープひずみが一定載荷応 力に比例するように $m_{H}=\mu$ +1 として, 式 (25) を書き 直すと,

$$
\begin{aligned}
& \frac{d}{d t}\left(\varepsilon_{c}{ }^{\mu+1}\right) \\
& \quad=(\mu+1) B_{H} \sigma(t)^{\dot{\mu+1}}
\end{aligned}
$$

式 (11) で $\eta_{*}(t)=$ const. と し, 式 (26) と比較すれば, モデルは水和完了後ひずみ硬 化法を表わすことがわかる.

なおひずみ硬化法は英国電 力庁によって Oldbury 原子 力発電所の $\mathrm{PC}$ 圧力容器の解 析に ${ }^{13)}$ ，また青柳らによって 同じ構造物を対象とした構造 実験の解析 ${ }^{14)}$ に用いられてい る.
以上 (1)，(2) から，ここで示したモデルは $q=1$ の とき水和の進行中はクリープ速度法（時間硬化法の特殊 形）となり，水和完了後はひずみ硬化法を表わすことが わかった．そして水和粘性モデルはこのような制限なし に用いることができる.

図一12には図中に示す階段状応力変化を加えた場合 のクリープの実測值と計算值を示す、計算に用いた $A$, $p, q$ と瞬間弾性係数は, 並行して行った一定応力の $\sigma=$ $75 \mathrm{kgf} / \mathrm{cm}^{2}\left(7.355 \mathrm{~N} / \mathrm{mm}^{2}\right)$ クリープ試験（材令 29 , 50,71 日で載荷）から求めたものである.この場合ひず みは, たとえば $t_{3}=71$ 日以後では, $t_{1}=29, t_{2}=50$ 日 として,

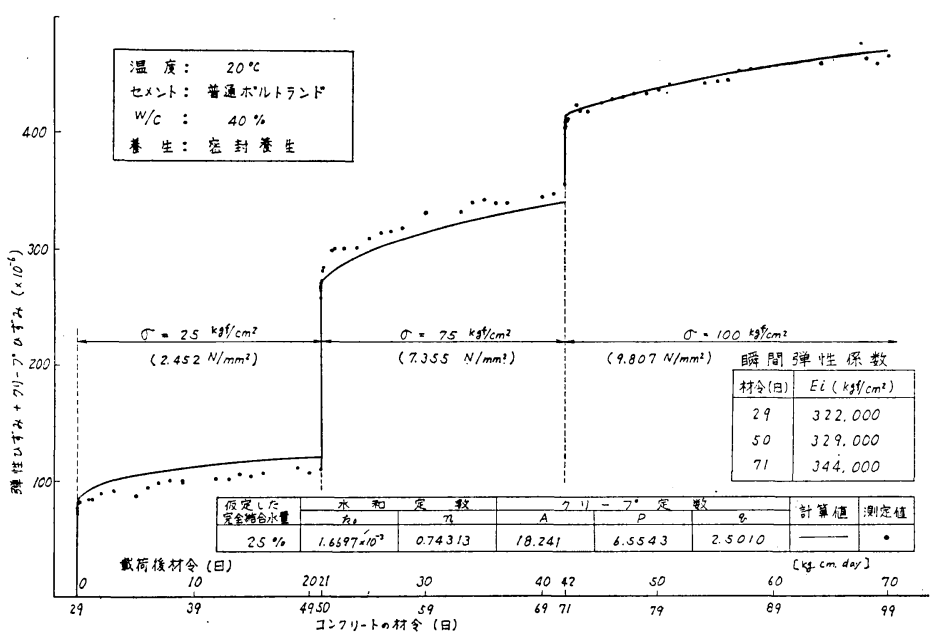

図一12 階段状応力変動下のクリープ

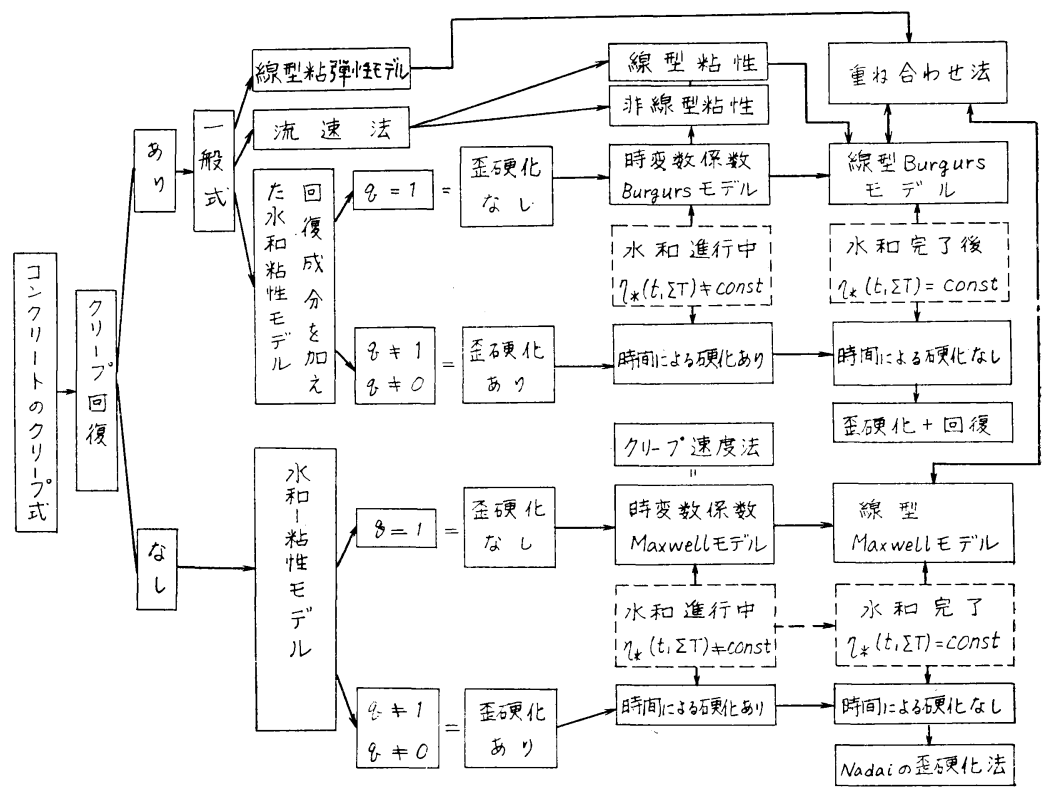




$$
\begin{aligned}
\varepsilon\left(t-t_{1}\right)= & \frac{\sigma_{1}}{E_{i}\left(t_{1}\right)}+\frac{\left(\sigma_{2}-\sigma_{1}\right)}{E_{i}\left(t_{2}\right)}+\frac{\left(\sigma_{3}-\sigma_{2}\right)}{E_{i}\left(t_{3}\right)} \\
& +\left[\int_{t_{1}}^{t_{2}}\left(\frac{\sigma_{1}}{\eta_{*}(s)}\right)^{q} d s+\int_{t_{2}}^{t_{3}}\left(\frac{\sigma_{2}}{\eta_{*}(s)}\right)^{q} d s\right. \\
& \left.+\int_{t_{3}}^{t}\left(\frac{\sigma_{3}}{\eta_{*}(s)}\right)^{q} d s\right]^{1 / q} \ldots \ldots \ldots \ldots \ldots \ldots \ldots \ldots \ldots \ldots
\end{aligned}
$$

図一13には種々のクリープ計算法の相互関係を示す.

\section{6. 水和・粘性モデルと温度との関係}

実験的に，コンクリートのクリープの温度による変化 は, 水の粘性係数の逆数の温度変化と同じオーダーであ $3^{1), 2)}$ (表一3 参照). モデルでは式 (11)〜 (14) から, 水 和完了後はクリープひずみは水の粘性係数の逆数に比例 する.またこのモデルでは，温度の上昇により水和が促 進し，クリープを減少させるはずであるのに実際にはク リープが増加する現象を矛盾なく表わすことができる. 任意の温度変化のもとでの水和進行の式が確立すれば, 式（11）からその場合のひずみが自動的に計算できる.

\section{表一3 各温度における水の粘性係数（ク）の逆数 と目標載荷材令 98 日の密封コンクリート

\begin{tabular}{|c|c|c|c|}
\hline 温 度 $\left({ }^{\circ} \mathrm{C}\right)$ & 20 & 40 & 70 \\
\hline 粘性係数の逆数 $\left(\eta^{-1}\right)$ & 1.00 & 1.68 & 2.70 \\
\hline $\begin{array}{l}\text { 載荷後 } 71 \text { 日における } \\
\text { クリープひずみ }\end{array}$ & 1.00 & 1.79 & 2.80 \\
\hline
\end{tabular} のクリープひずみの比較1),2)}

(相対值)

\section{7. 引張りクリープヘの拡張}

これまでの考察では, 結晶の初期接触長さは零 $(l=0)$ と仮定してきたので，モデルが最初に引張り応力を受け るならば，前掲の図一7からただちに破壊する，そこで 理論を引張りにも拡張 するために $l=l_{1}\left(t=t_{1}\right)$ と仮定 し，対応する “潜在ひずみ”を $\varepsilon_{0}$ とする. その場合， $\sigma(t) \geqq 0$ (圧縮) のとき, $d \varepsilon_{c} \geqq 0$, また $\sigma(t) \leqq 0$ （引
ここでは形式的に $m$ 個の Voigt 要素を直列に加えて, クリープ回復性成分を表現した。ただし $\lambda_{i}$ は $i$ 番目の Voigt 要素の緩和時間 $\left(\eta_{v i} / E_{v i}\right), E_{v i}, \eta_{v i}$ は各 Voigt 要素の弾性係数と粘性係数を表わす.

ここで $t$ が十分大きな場合を考える．そのとき, $\eta_{*}(t)$ $=\eta_{*}(\infty)=$ const. であるから, 圧縮クリープは $\sigma(t)=$ $\sigma_{+}=$const. $>0,\left(t \geqq t_{1}\right)$ を式 $(28)$ に代大し, クリープ 回復性成分ははぶいた場合には,

$$
\begin{aligned}
\varepsilon\left(t-t_{1}\right) & =\frac{\sigma_{+}}{E_{i}(\infty)}-\varepsilon_{0} \\
+ & {\left[\varepsilon_{0}^{q}+\left(\frac{\sigma_{+}}{\eta_{*}(\infty)}\right)^{q}\left(t-t_{1}\right)\right]^{1 / q} }
\end{aligned}
$$

引張りクリープは, $\sigma(t)=\sigma_{-}=$const. $<0, \quad\left(t \geqq t_{1}\right)$ と して,

$$
\begin{aligned}
\varepsilon\left(t-t_{1}\right) & =\frac{\sigma_{-}}{E_{i}(\infty)}-\varepsilon_{0} \\
+ & {\left[\varepsilon_{0}^{q}-\left(\frac{\left|\sigma_{-}\right|}{\eta_{*}(\infty)}\right)^{q}\left(t-t_{1}\right)\right]^{1 / q} }
\end{aligned}
$$

図一14にこれらの式による圧縮クリープと引張りクリ ープの形状の相違を示す. このモデルでは, 圧縮応力の もとでのクリープは有限の速度で開始し，その速度は時 間とともに減少するが，引張りの場合は圧縮クリープと 同じ速度で始まったクリープは，ひずみ $-\varepsilon_{0}$ に達した とき速度は無限大となり，破壊する．実は，これらの曲

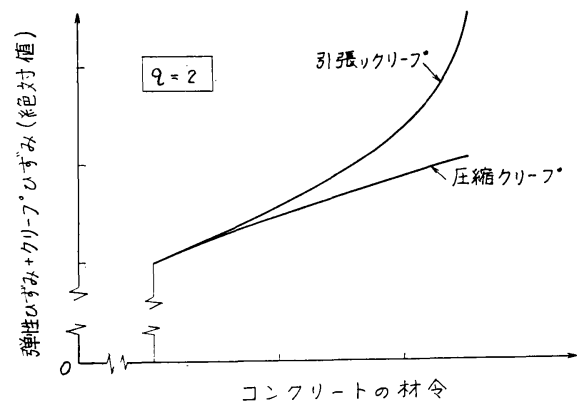

図一14 圧縮と引張りクリープ曲線の形状の相違 （回復性成分を除く） 張り) のとき $d \varepsilon_{c} \leqq 0$ と仮定し, $\varepsilon_{c}+\varepsilon_{0} \geqq 0$ でありさらに $\varepsilon_{c}(0)=0$ であることを考慮す ると,

$$
\begin{aligned}
\varepsilon\left(t-t_{1}\right) & =\int_{t_{1}}^{t} \frac{1}{E_{i}(s)} \frac{d \sigma(s)}{d s} d s-\varepsilon_{0} \\
+ & {\left[\varepsilon_{0}^{q}+\int_{t_{1}}^{t} \operatorname{sgn}(\sigma) \frac{|\sigma(s)|^{q}}{\eta_{*}^{q}(s)} d s\right]^{1 / q} } \\
+ & \sum_{i=1}^{m} \frac{1}{\eta_{v i}} \int_{t_{1}}^{t} \sigma(s) \exp \left[-(t-s) / \lambda_{i}\right] d s
\end{aligned}
$$

ただし，

$$
\operatorname{sgn}(\sigma)=\left\{\begin{array}{rr}
-1, & (\sigma<0) \\
0, & (\sigma=0) \\
1, & (\sigma>0)
\end{array}\right.
$$

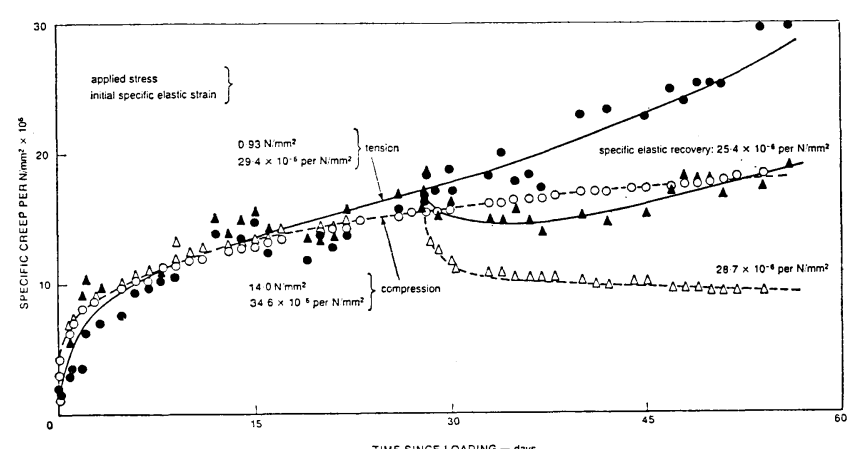

TIME SINCE LOADING - days

図一15 Brooks \& Neville ${ }^{15)}$ の実験にみる圧縮と引張りクリープ 曲線の相違（水中養生・材令 28 日載荷 56 日除荷） 
線は初期抵抗を考慮しなかった場合のクリープ曲線の 2 つの分枝を表わしている. なお 図一15 には Brooks \& Neville $^{15)}$ の実験結果を示す. 図一14 に回復性成分を加 えれば，これときわめて類似したものとなる.

このモデルでは, クリープは一定応力のもとでも応力 に比例しない. 圧縮の場合 $t-t_{1} \rightarrow 0$ のとき, ひずみは $\sigma^{q}$ に比例するが, 時間の経過とともに初期抵抗の影響 は消失し, 応力 $\sigma$ に比例するようになる. 引張りの場合 $t-t_{1} \rightarrow 0$ のとき, ひずみはやはり $\sigma^{q}$ に比例するが, 時 間の経過とともにその非線形性は拡大され, 載荷応力の 大きいものから一定のひずみ $\left(-\varepsilon_{0}\right)$ に達したときに破 壞していく.

引張りクリープの破断時間は (水和完了後),

$$
t-t_{1}=\eta_{*}^{q}(\infty) \varepsilon_{0}^{q} / \sigma^{q}
$$

となるが, まったく同形の式が金属クリープの分野で異 なった考えから求められ,一般に受け入れられている ${ }^{12)}$.

引張りと圧縮が組み合わさった応力履歷のときも矛盾 が生じないことは容易に確かめられる.

\section{8. 結論}

内部水の粘性とセメントの水和を考慮したコンクリー トのレオロジー・モデルはかなり広範なコンクリートの クリープ挙動を説明することができ, 載荷材令や水セメ ント比の影響等については, 実験值を相当によく表わせ ることがわかった. また提案したモデルは，ひずみ硬化 法やクリープ速度法を特殊な場合として含んでいる.

このようにコンクリートのクリープの研究に微視的観 点を導入していくことはきわめて必要であることが確認 された。

最近, 施工上ポンプクリートの使用が増加し, コンク リート中のモルタル分が多くなり, クリープが増大し, 今後ますます安全性の確保のため, クリープ問題が重要 な位置を占めるようになると考えられる.さらにデータ を蓄積し, クリープ回復や乾燥クリープを含むように理 論を搪張してゆきたいと考えている.

終わりにあたり, 故佐藤常三・神山一両教授に厚くお 礼申し上げます. また種々ご配慮いただいた電力中央研 究所 垣谷正道局長 - 同土木技術研究所 千秋信一所長 . 安田正幸部長 - 阿部博俊 - 青柳征夫両室長 - 田辺忠顕前 室長はじめ同所の皆様に感謝いたします. また卒論学生 として実験に協力された日下野弘 ・田村幹夫 ・ 斉智清
秀・北沢秀幸 - 秋山憲朗 - 江村芳郎 - 高見沢仁治 - 新開 千弘の諸氏の協力なしには，この論文は決して世に現わ れ得なかったでありましょう。

\section{参 考 文 献}

1) Seki, S. and M. Kawasumi : Creep of concrete at elevated temperatures, Concrete for Nuclear Reactors, ACI SP-34, Vol. 1, pp. 591 638, 1970.

2）河角 誠・関 慎吾・笠原 清・栗山武雄 : 高温度下に 掞けるコンクリートのクリープ, 電力中央研究所技術第 二研究所報告, 研究報告 : 72018, 1973 年 3 月.

3）関 慎吾・笠原 清・栗山武雄・河角 誠 : セメントの 水和進行率から求まるコンクリートの有効セメント水比 と圧縮強度との関係について, 土木学会論文集, 第 146 号, pp. 38 46, 1967 年 10 月.

4） Czernin 著・徳根吉郎訳 : 建設技術者のためのセメント・ コンクリート化学, 技報堂, 1969 年.

5）君島博次・北原義浩：マスコンクリートのクリープ進行 と回復, 電力中央研究所技術研究所所報, Vol. 14, No. 6 , pp. $117 \sim 123,1964$ 年 4 月.

6) Neville, A.M. : Creep of Concrete, Plain, Reinforced, and Prestressed, North-Holland Publishing Co., 1970.

7) Parrot, J.M. : A study of basic creep in relation to phase change in cement pastes, RILEM Colloquium: Creep of Concrete, Precirculated Notes, April 1978.

8) 米国内務省開拓局編・近藤泰夫訳 : コンクリートマニュ アル (第 8 版), 国民科学社, 1978 年.

9) Bažant, Z.P. and E. Osman : On the choice of creep function for standard recommendations on practical analysis of structures, Cement and Concrete Research, Vol. 5, pp. 129 138, 1975.

10) Powers, T.C. : Mechanisms of shrinkage and reversible creep of hardened cement paste, The Structure of Concrete and its Behaviour under Load, Proc. of Int. Conf. London, pp. 319 344, Sep. 1965.

11) Bažant, Z.P. : Thermodynamics of interacting continua with surfaces and creep analysis of concrete structures, Nuclear Engineering and Design, Vol. 20, pp. 477〜505, 1972.

12）オドクヴィスト・ハルト共著・村上澄男訳 : クリープ強 さの理論, 培風館, 1967 年.

13) Carmichael, G.D.T. and I.W. Hornby : The strain behaviour of prestressed concrete pressure vessels, Magazine of Concrete Research, Vol. 25, No. 82, pp. 5 16, March 1973.

14）青柳征夫・大沼博志・川崎道夫：温度勾配を与えたプレ ストレストコンクリートはりに関する実験的研究, 電力 中央研究所技術第二研究所報告, 研究報告 : 70003, 1970 年 8 月.

15) Brooks, J.J. and A.M. Neville: A comparison of creep, elasticity and strength of concrete in tension and in compression, Magazine of Concrete Research Vol. 29, No. 100, pp. 131 141, September 1977.

(1981.4.10 - 受付) 